\title{
Our Space: Online Civic Engagement Tools for Youth
}

\author{
Kate Raynes-Goldie and Luke Walker
}

TakingITGlobal Research

\section{Introduction}

The Internet is quickly becoming an integral part of life. The embedded role of the Internet in everyday life is perhaps most prevalent for youth, particularly in developed countries: in 2005, the PEW Internet \& American Life Project found that 87 percent of American teens go online, and half of them report going online every day. ${ }^{1}$ Many "real world" activities can now take place online-including many social-networking and community-building tasks that go well beyond traditional uses of information and communication technologies. Civic engagement, as other authors in this volume have presented, is one of the areas of activity that has made the transition to the online realm, with varied forms of implementation and varying degrees of success.

There is currently no established methodology for evaluating the effectiveness of online civic engagement sites, for youth or other segments of the population. We believe a shift in perspective of what civic engagement is and how it could occur online is necessary to evaluate the sites, methodologies, and tools that promote civic engagement among youth. Just as Jimmy Wales, founder of Wikipedia, argues that social software should empower rather than replace traditional forms of interaction, we see the role of online civic engagement tools as enhancing and empowering real-world action:

A lot of programmers, seem to me to think that the whole point of social software is to replace the social with the software. Which is not really what you want to do, right? Social Software should exist to empower us to be human ... to interact ... in all the normal ways that humans do. $^{2}$

Preliminary research points toward this paradigm shift. Research conducted by Michael Delli Carpini, ${ }^{3}$ of the Annenberg School of Communications, as well as research conducted by TakingITGlobal for the J. W. McConnell Family Foundation, ${ }^{4}$ have found that efforts in the online civic engagement space are often more strongly suited for enabling or more deeply engaging young people who are already civically minded. MySpace and digital youth expert danah boyd has blogged ${ }^{5}$ and written extensively about the importance of the latest generation of online spaces for youth in developed countries who, for various reasons, have low access to physical hangout spaces, such as the mall or the park. ${ }^{6}$ MySpace is so popular, she argues, because it acts as a digital public space where youth can hang out online with

We thank Jennifer Corriero, Michael Furdyk, Xingtao Zhu, and Nick Moraitis for their assistance throughout the development of this chapter, with special thanks to Jo-Anne Raynes and Emily Kornblut, as well as John Horrigan from the Pew Internet \& American Life Project, for their indispensable feedback. 
their friends. So, providing civic engagement opportunities online-where youth already spend their time-has great potential. It is accessible, familiar, and does not ask youth to change their habits or step outside their comfort zones to get involved.

We have found that interactive Web sites and online communities aimed at promoting civic engagement, activism, or community involvement among youth are generally facilitators of the civic engagement that occurs in the offline world, but not necessarily the places where that engagement occurs. Our initial research shows that this role of online civic engagement tools is a valuable precursor to engaging young people in their physical communities.

Drawing on the work of Montgomery, Gottlieb-Robles, and Larson, ${ }^{7}$ we define civic engagement as any activity aimed at improving one's community. Our initial findings point to online civic engagement sites as primarily facilitators of action, rather than places of action. While actions such as writing to an official or signing a petition are positive actions that do occur online, the majority of civic engagement activities resulting from online engagement actually happen in the offline world. Online engagement sites are facilitators of these offline activities, providing access to three keys of change: information, people, and tools to organize. These sites enable youth to access information about issues, other relevant organizations, and how to take action effectively. They can connect with their peers to get feedback and support, and organize around issues important to them. Armed with the support of like-minded individuals, tools to organize, and the right information, youth are empowered by these Web sites to step out into the offline world to volunteer, raise awareness, educate others, and start their own organizations.

This chapter consists of three parts. First, we present an overview of TakingITGlobal (TIG), where we are both employed. TIG runs TakingITGlobal.org, one of the largest and most sophisticated civic engagement sites in the world. Its purpose is to develop the capacity of young people to effect change in their communities. TakingITGlobal.org was one of the first of a growing number of interactive and social online engagement sites. Over five million people from around the world have visited since it was launched in 2000.

Second, we present initial findings from a survey we conducted to discover how young people are using TakingITGlobal.org and other online civic, community, or activist sites. Our aim was to find out how youth are using online tools and to determine what civic engagement activities they are involved in.

Finally, we look at these survey findings in the context of online community theory to create a snapshot of the current landscape of online youth civic engagement. We then conclude with a discussion of key learnings and areas for improvement. We hope our findings will be useful in guiding future developments of online civic engagement sites.

\section{TakingITGlobal: New Tools for Youth-led Engagement}

TakingITGlobal.org grew from the recognition that youth are not apathetic about social issues; rather they lack access to appealing forms of engagement. Working with this concept, Jennifer Corriero, Michael Furdyk, and a team of other young people launched TakingITGlobal.org in 2000. In its early iterations, the site had member and organizational profiles and discussion boards. Other tools, from blogs to an online art gallery, to project planning tools followed. ${ }^{8}$ The site has evolved into a complex platform tying together the core tools that young people use so readily_blogs, discussions boards, podcasts, and instant messaging-combined with collaborative action-planning tools, background information 
Table 1

TakingITGlobal members by region (as of January 10, 2006) ${ }^{\mathrm{a}}$

\begin{tabular}{lll}
\hline North America & 43,354 & $30.36 \%$ \\
Africa & 31,624 & $22.14 \%$ \\
Asia & 28,895 & $20.23 \%$ \\
Europe & 17,572 & $12.30 \%$ \\
Middle East North Africa & 9,285 & $6.50 \%$ \\
Australia and New Zealand & 5,255 & $3.68 \%$ \\
South America & 4,486 & $3.14 \%$ \\
Central America and the Caribbean & 1,749 & $1.22 \%$ \\
Pacific Islands & 598 & $0.42 \%$ \\
\hline
\end{tabular}

aTakingITGlobal, Membership Update (January 10, 2007).

on a broad area of social issues, and connections to relevant organizations, groups, and their peers.

The development of the TakingITGlobal.org platform has been driven by user feedback and feature requests. TakingITGlobal.org registered its 100,000th member in the fall of 2005 and at the time of writing had over 130,000 members from two hundred countries (see Table 1). Through the efforts of a global team of volunteers, TakingITGlobal.org is available in English, French, Spanish, Russian, Dutch, Italian, Portuguese, Romanian, Turkish, Chinese, and Arabic. The site is further localized with country sites, or portals to country-specific information. The average member is twenty-two years old and spends an average of thirtyfour minutes per session on the TIG site. ${ }^{9}$

The TakingITGlobal.org online community is accessible and available to anyone with an Internet connection, anywhere in the world. The site supports learning, dialogue, collaboration and action on key topics, including:

- $\quad$ Arts and media

- Culture and identity

- Human rights and equity

- Learning and education

- Environment and urbanization

- Work and economics

- Health and wellness

- Peace, conflict and governance

- Technology and innovation

Social, Organizational, and Informational Tools

TakingITGlobal.org provides many tools similar to those of commercial social networking or online community sites, but it does so within the context of civic engagement. In their book Wikinomics, Don Tapscott and Anthony D. Williams describe the key difference between TakingITGlobal.org and its commercial counterparts:

Like MySpace and Facebook, TakingITGlobal harnesses all of the latest tools, such as blogging, instant messaging, and media sharing. But it promotes a decidedly different kind of social networking. Rather than list their favorite movie stars and music tracks, members list information about the languages they 
speak, the countries they have visited and the issues they're most concerned about. Members link to other members' profiles when they share similar interests, and those links create social connections that lead to new friendships and projects. ${ }^{10}$

The other key difference between TakingITGlobal.org and its commercial counterparts is that TakingITGlobal.org embeds its social-networking tools within the context of civic engagement and activism by providing relevant resources and informational tools (organization databases, issue directories, etc.). These tools allow members to find and share the information they need to create change in their communities. The information and resources found on the site are created by members and by TakingITGlobal staff or partners. The benefits of integrating tools that connect people with informational tools are twofold. First, it provides access to two key ingredients for action: people and information. Second, in providing youth-friendly social tools such as blogs and profiles, youth are engaged on their own terms and with the same types of tools they are already familiar with and use everyday. Providing youth with access on their own terms means they are more likely to engage.

TakingITGlobal.org's social tools consist of standard Web tools (see Table 4): blogs, profiles, and social-networking tools, a Web messenger and discussion forums, all of which help members to find, connect, and network with each other. TakingITGlobal.org also provides tools for organizing, such as Projects and Groups, which its commercial counterparts such as MySpace and Facebook, lack. These tools help members to organize around an issue or project. The informational tools on TakingITGlobal.org revolve around member content and include Understanding the Issues, the Global Gallery (photography), Member Stories, Panorama (creative writing), Intersections (mixed media), and TIG Magazine. Members also have access to extensive directories of events, organizations, and professional opportunities, to which they can add as well as search. These directories help members find volunteer opportunities, youth-serving organizations or events focused on various social issues and decision-making processes, such as the World Summit on the Information Society. TakingITGlobal.org also provides downloadable resources such as the Workshop Kit, Guide to Action, and information on running Open Forums.

All of the social, organizational, and informational tools on TakingITGlobal.org are tightly integrated and linked. For example, most of the items that are listed on a profile page are clickable, leading to related resources or lists-so clicking a name of a project on someone's profile will direct you to the Project page. This makes it easy for members to move between informing themselves on a resource page and taking action through a community tool. It also makes it easier to find other members interested in the same issues.

\section{Bridging Offline and Online Engagement}

TakingITGlobal consists of two intertwined yet distinct areas-TakingITGlobal's online community (TakingITGlobal.org) and its offline engagement areas. Most of TakingITGlobal's offline engagement activities are strongly linked or supported through the online components. Reflecting the generation it serves, TakingITGlobal does not strongly distinguish between online and offline engagement.

TakingITGlobal's offline engagement focuses on increasing the collaboration between youth-serving organizations both regionally and globally, and mainstreaming youth involvement into international processes, such as United Nations summits. Creating Local Connections (CLC) provides local staff support to youth-serving organizations. Their

role is to facilitate the effective use of TakingITGlobal.org tools to better collaborate and overcome some of the barriers specific to youth-led organizations. ${ }^{11}$ The CLC program 
served to build a body of high-quality content and inspirational member stories within the TakingITGlobal.org community, enhancing the experience and appeal of the site for all members.

In 2004, Microsoft Russia funded the CLC pilot, which won an award for best youth Internet project for youth at Russia's Festival of Youth Non-Commercial Projects. ${ }^{12}$ The Russian CLC project began with the translation of the site into Russian (http://ru.takingitglobal.org), one of TIG's first multilingual efforts. By the end of the yearlong project, TIG's Russian membership had grown by nine hundred individuals and eighty organizations.

In 2006 the J. W. McConnell Family Foundation funded a three-year cross-Canada version of CLC. The program placed a coordinator in each province and territory, and engaged Francophone and Aboriginal Engagement Coordinators to meet the needs of these populations. In 2007, the West African version of CLC will implement the program in several countries in the region. In each country, local TIG staff works within partner organizations, reaching out to local organizations in their region, and building a substantial body of locally relevant content on the TakingITGlobal.org site.

International political or economic events present a set of participation barriers for young people. While critical decisions affecting the lives of young people are often made through major international policy processes, there is frequently little or no opportunity for youth engagement. Even if there is no formal barrier to youth involvement, such as registration restrictions, there are often logistical or financial obstacles. The UN World Summit on the Information Society (WSIS) in 2005 was a major opportunity for TIG, as it addressed the digital divide, a major area of interest for many TakingITGlobal.org members. Working with a coalition of youth-led and youth-serving organizations, TIG facilitated the youth caucus, mainstreaming youth participation into the Summit. Through the coalition's work, not only was there a prominent youth presence at the Summit, but hundreds of young people attended the WSIS preparatory meetings, running and speaking on high-level panels and lobbying delegates. ${ }^{13}$ Throughout the process, young people were able to use TakingITGlobal.org's tools throughout the process to learn how to contribute and to share experiences with each other.

The XVI International AIDS Conference, held in Toronto in August 2006, presented TIG with another opportunity to mainstream youth participation. TIG and its partners Family Health International, the Global Youth Coalition on HIV/AIDS, along with several other organizations, worked together as the Toronto Youth Force. Representatives of the Youth Force were involved in all aspects of conference planning, including the development of an official Youth Program for the conference. TIG developed the Youth Program site (http://youth.aids2006.org) and ensured that the content created by over a thousand youth delegates would be sustained well beyond the short life of the typical conference Web site. By tying the conference's youth site to TIG's existing tools and user system, it ensured that youth media and networks created at the conference would exist simultaneously both online and offline, and continue to exist once the conference organizers shut down the main site.

Through the organization's work with networks like the Global Youth Coalition on HIV/AIDS (GYCA) and the Youth Employment Summit (YES), TakingITGlobal.org has, in many ways, become a network of networks. This precedent was set early on, when Nation1, an outgrowth of the MIT Media Lab's Junior Summit, decided to move its network to the TakingITGlobal.org site, rather than launching its own. ${ }^{14}$ Work with groups like YES has drawn groups of active youth into the TakingITGlobal.org community, who can then serve as valuable mentors and sources of inspiration for other members. 


\section{TakingITGlobal.org's Tools in Action}

Bossman Boakye, a TakingITGlobal member from Ghana, provided us with this story of how he used TakingITGlobal's tools to start a civic engagement organization in his country:

I got in touch with a friend who happened to be a member of TIG three years ago and he introduced me to this great site.

At first, what I used to check on the site was events and opportunities. I had a great zeal to travel to any youth programme so I found this site very interesting and worthy of links to youth events around the world.

During one of these searches, I came across an information on World Assembly and I decided to write to them to ask for more information. I was replied with the information that a new initiative known as Student World Assembly was in the pipeline to be introduced and that I could join and make inputs. Basically, this initiative seeks to promote democracy and civic participation globally.

I presented a proposal to the officials of Student World Assembly on the setting up of the organisation in Ghana. I must say that this is where TIG became of immense benefit to me. I had to visit the discussion board (English section) to discuss my idea with other people. I also read more on democracy and other issues the SWA was discussing on their website www.studentworldassembly.org on Understanding Issues. It is during one of my visits

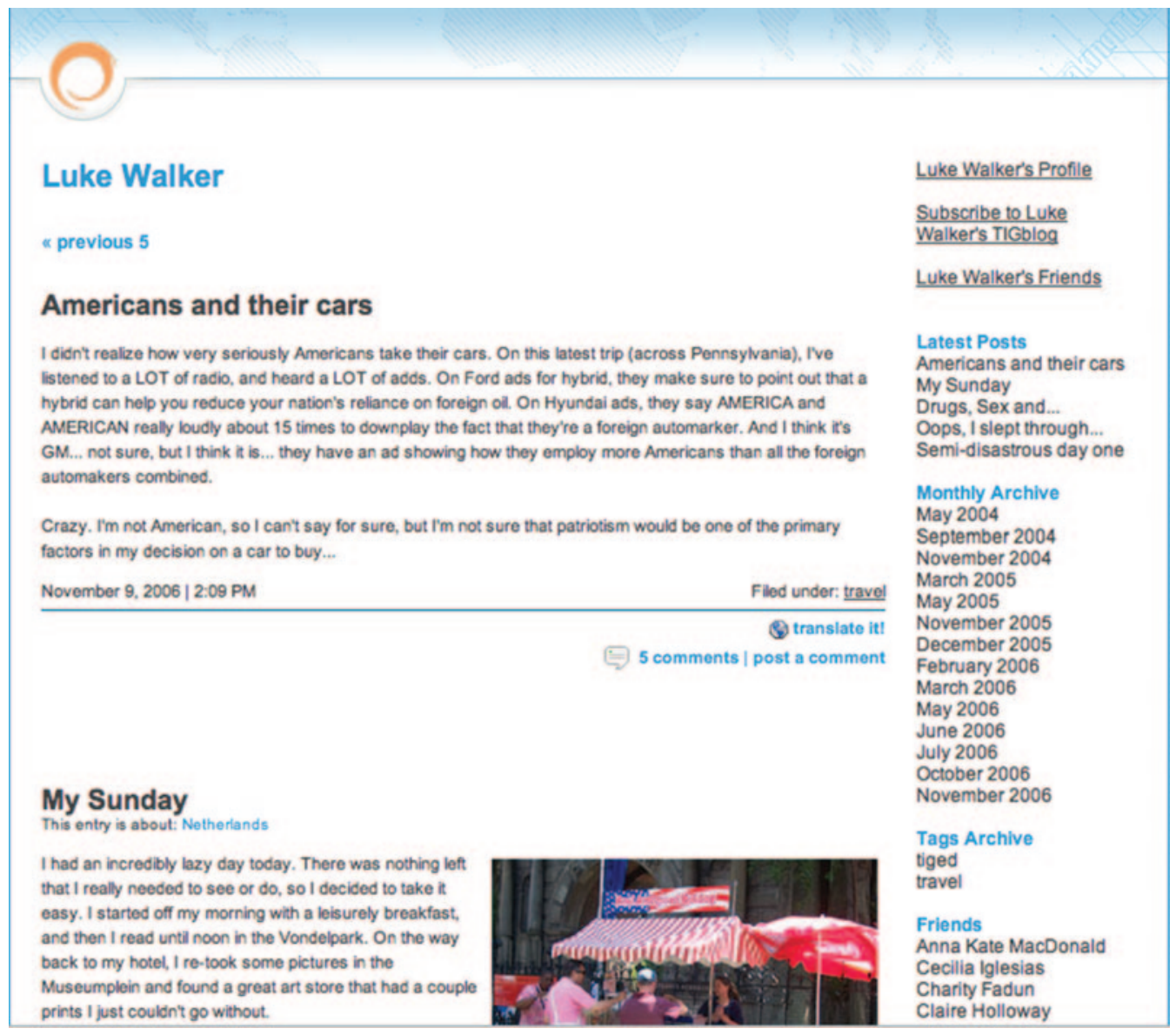

Figure 1

A TakingITGlobal member blog. 


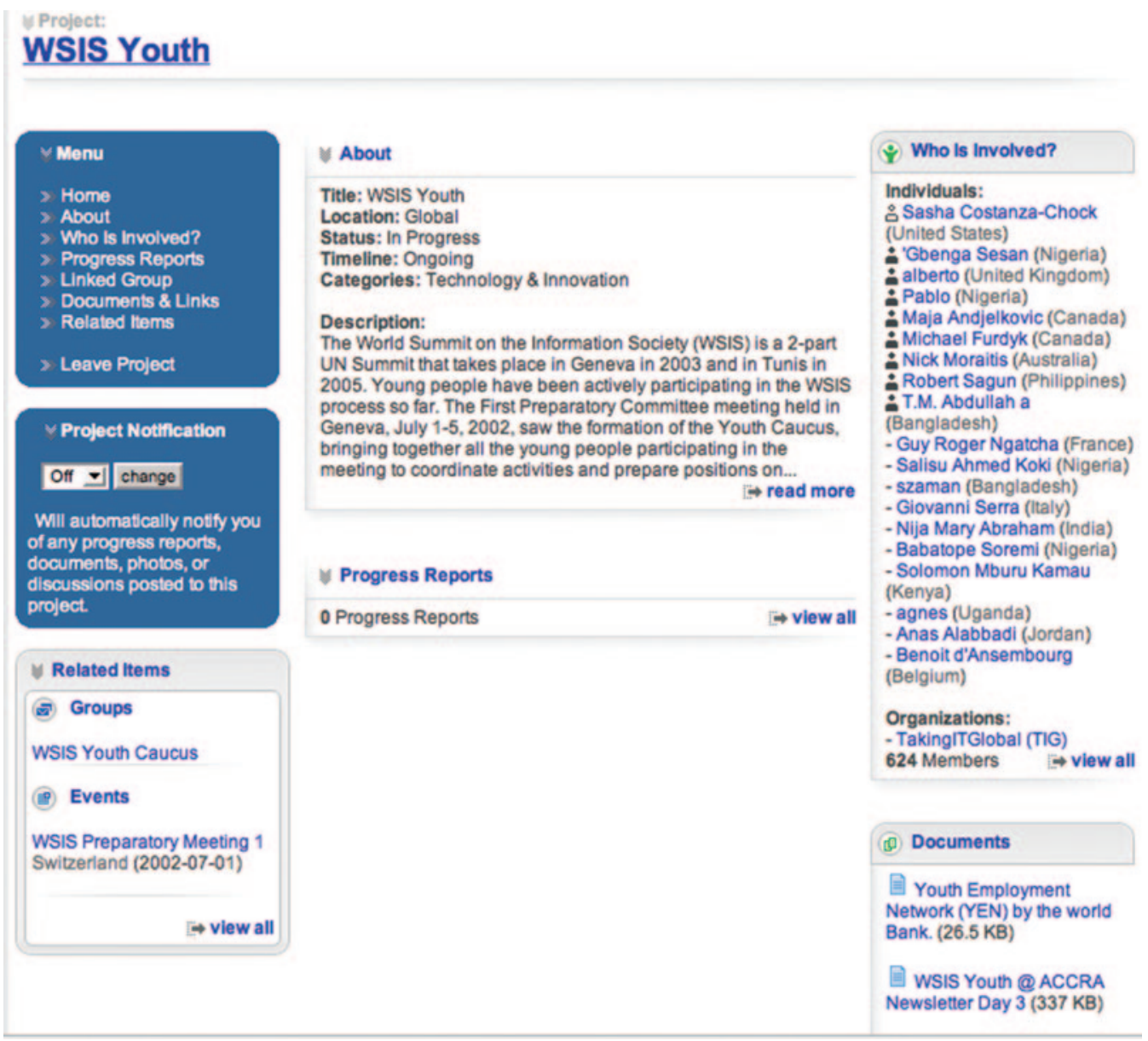

Figure 2

A TakingITGlobal project page.

to this site when I met a friend who also shared in my initiative and visions and who also happened to be a Ghanaian.

We met and he took me on a visit to very beneficial links at TIG website for me where I got to know how to write proposals, start up youth and students NGOs, fundraising, etc.

I must say that, TIG has helped me a lot in setting up Student World Assembly in Ghana which can now boast of over 10 established chapters in tertiary institutions in Ghana.

I am now the programmes and growth officer for the organization and I link up my success and excellence to TIG; I must say that it is a great site for youth endeavours.

This type of story provides insight into how youth are actually using different online tools, such as those of TakingITGlobal.org, to engage and make positive changes in their communities. This and similar anecdotes provide evidence of the efficacy of TakingITGlobal.org's role in assisting youth in making positive change. ${ }^{15}$ Several project areas are working on implementing evaluation structures, including the education program and CLC Canada. Results of these more systematic research efforts will be available in late 2007. 


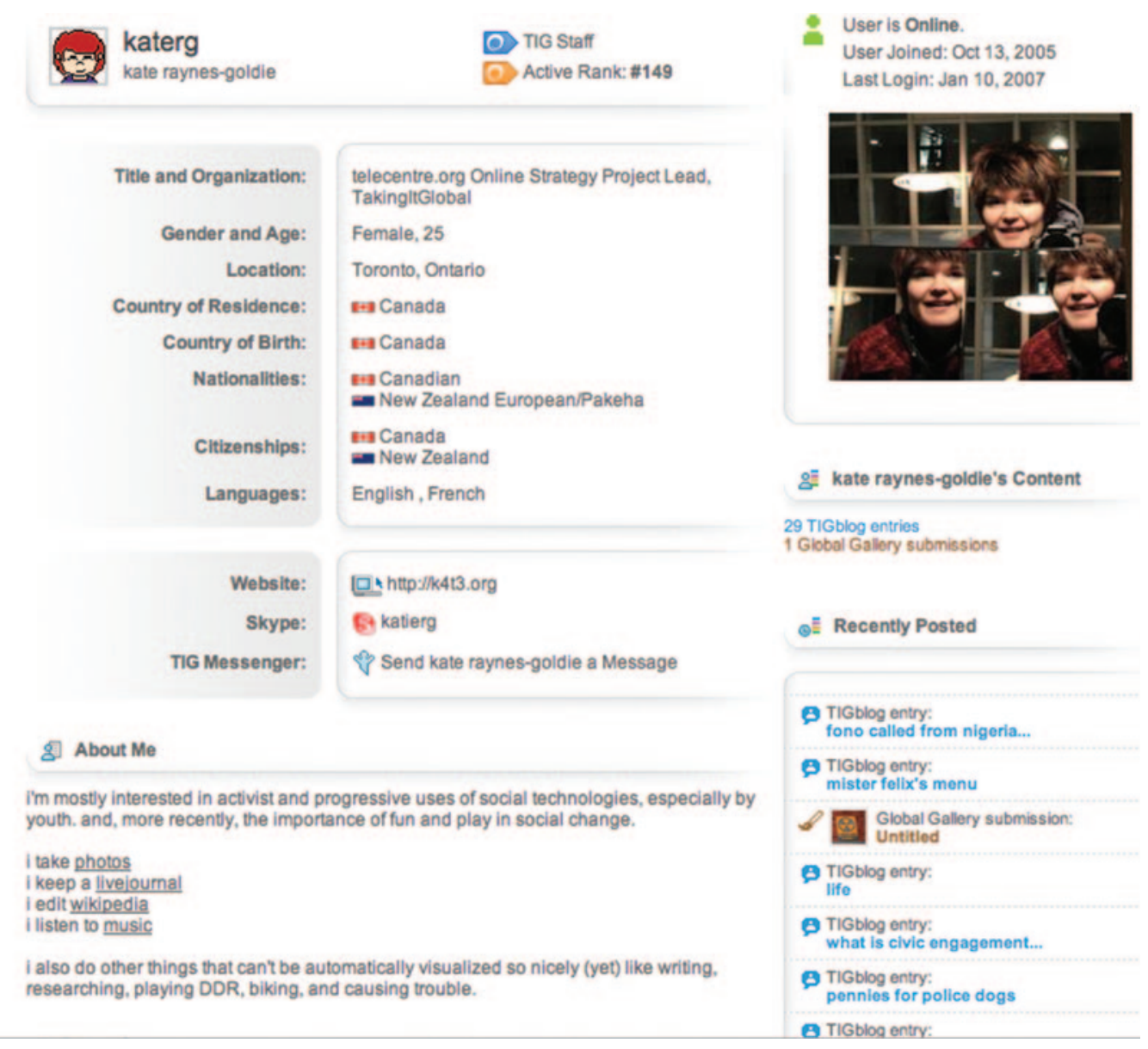

Figure 3

A TakingITGlobal member profile.

\section{Funding and Sustainability}

TakingITGlobal operates on a budget of approximately $\$ 1$ million. Its education and local engagement programs are funded by grants from the J. W. McConnell Family Foundation, Walter \& Duncan Gordon Foundation, Royal Bank Financial Group, Microsoft, and the Canadian International Development Agency (CIDA). Though critical, grant funding has limitations especially when most grants occur on a one-time basis and offer no guarantees for renewed commitment. Project-based funding has been accessed from the UN Millennium Campaign to create campaign kits on the Millennium Development Goals, and from UNESCO to run a project on urban violence and youth.

TIG's other major source of funding is technology development work. TIG leverages the customized platform it has created for its own online community to build similar tools for other organizations, ranging from the Digital Divide Network (http://www.digitaldivide.net, which has since become an internal project of TakingITGlobal) to Greenpeace, Oxfam 

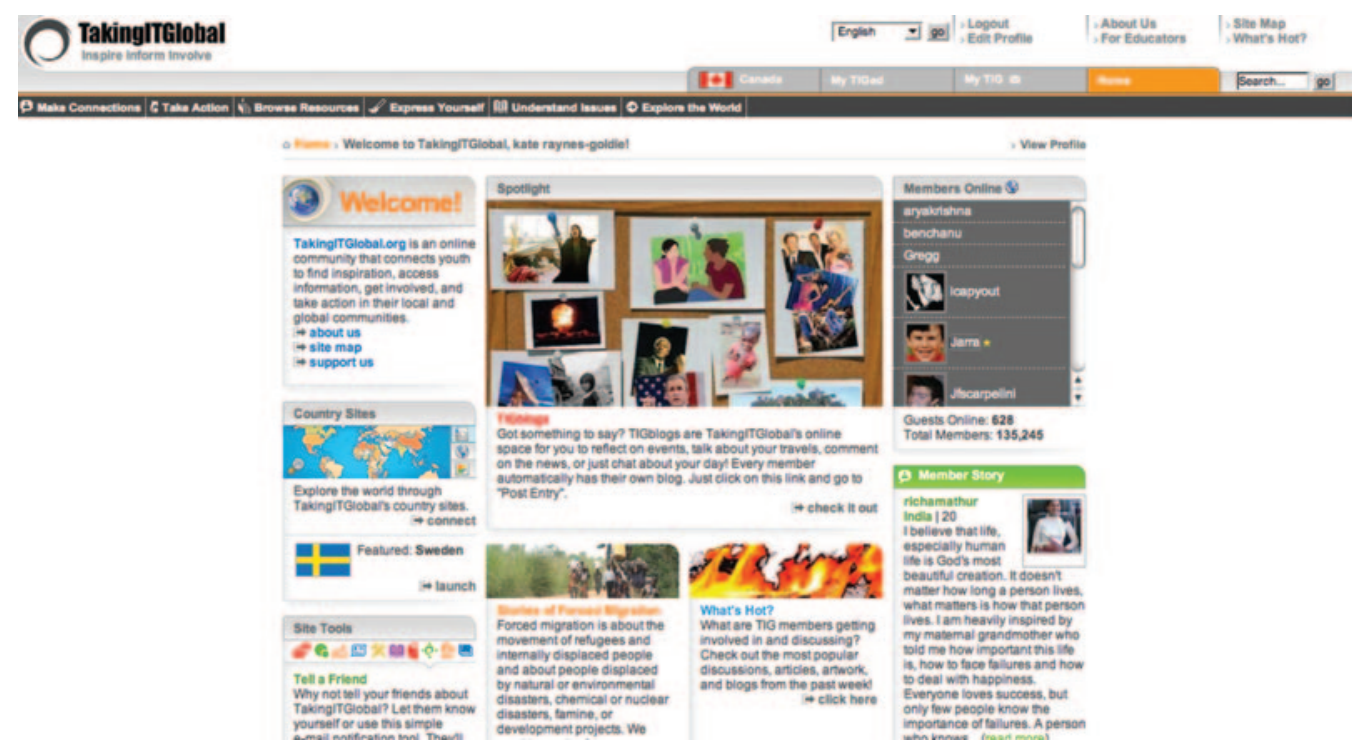

Figure 4

The TakingITGlobal.org Home Page.

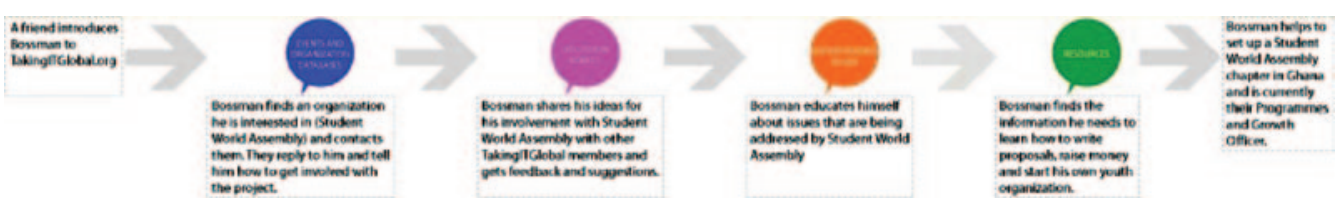

Figure 5

Bossman's steps to action.

Canada, and the Adventure Ecology. This strategy provides partners with excellent online tools that would otherwise be unaffordable, while simultaneously giving TakingITGlobal access to new tools to incorporate into its own online community. A project with the Youth Employment Summit (http://www.yesweb.org/), for example, led to the development of TakingITGlobal's project pages, now a core offering that allows any TIG member to create, manage, and promote an action project. ${ }^{16}$

Increasingly, TakingITGlobal's education program (http://www.TIGed.org) is a source of membership growth and financial sustainability. TIGed is a virtual classroom system combined with educational materials developed from TakingITGlobal.org content, allowing educators to create authentic learning experiences about global issues by using tools students are familiar with. Reaching out to teachers helps to involve those students who are not already engaged or civically minded, in addition to appealing to those who are looking to become more or better engaged. TIGed has created new opportunities for TIG to generate revenue from users: whereas individual membership is free, teachers, schools, and districts are charged for the additional tools that TIGed provides. 


\section{Youth Survey Findings}

Presently, no methodology exists for evaluating the efficacy of online civic engagement sites. This lack of framework and standardized metrics are a barrier to funding and delivering the best tools for facilitating the offline civic engagement of youth. In deciding to conduct a survey of both TakingITGlobal members and online youth generally, we wanted to take the first steps toward discovering and assessing the offline impact of online engagement. We know anecdotally that youth are using TakingITGlobal.org's tools to better their communities, but we have not been able to map the connections between the online tools and offline youth engagement. We wanted to uncover TakingITGlobal.org's role in facilitating the outcomes our members have reported, and find out more specifically which tools TakingITGlobal.org members were using and how. We also wanted to know more about how youth-both TakingITGlobal.org members and others-were using other online tools and sites, and what actions they might be taking as a result.

For two weeks in the fall of 2006, we conducted an exploratory survey, promoted through TakingITGlobal.org and several other blog sites, to uncover how young people use online tools for the purposes of civic engagement. The survey solicited 769 responses from both members of TakingITGlobal.org and youth who found our survey through a number of other blog sites (classified as "Other Respondents" in Tables 2 and 3): 46.6 percent of respondents were male and 50.5 percent female (the remainder did not indicate their gender); 18.3 percent of respondents were under the age of twenty-one, 75.16 percent were between twentyone and thirty, and 1.95 percent were thirty-one or older. The remainder did not indicate their age. The survey received responses from 111 countries. The top ten countries with the most respondents were Canada (146), the United States (50), Philippines (45), Australia (44), Nigeria (42), Pakistan (33), the United Kingdom (32), Kenya (24), Turkey (22), and India (21).

We learned that young people who are interested in civic, community, or activist issues are looking to the Internet for information about causes important to them, connections to like-minded peers and organizations, and for ways to organize and mobilize. When these needs are met, youth report in our qualitative section that they are able to make positive change in their lives and in their communities, demonstrating that the action or result of online engagement is occurring offline.

The youth survey consisted of two sets of questions: one set focused on the uses of online tools for civic engagement and the other on TakingITGlobal.org's toolset. As the responses indicate (Tables 2 and 3), young people who responded to our survey are interested in civic issues, and that interest can lead them to take offline action.

Survey respondents were asked to characterize their behavior as NA/Never, Rarely, Sometimes, and Often. The tables below summarize the percentage of Often responses for the two survey groups: TakingITGlobal.org members and general online youth respondents.

While this is a sample of young people who are more likely to be engaged according to their online activities, we note that the participation rate in voting is 64.7 percent and those likely to attend events aimed at effecting change is 43 percent. Yet there is room for improvement in the other action areas.

Several other researchers in this field, including Montgomery, Gottleib-Robles, and Larson, ${ }^{17}$ have noted that while young people for the most part seem to have an interest in the issues affecting their communities, this interest is only modestly translated into action. In his chapter in this volume, Bennett points to the "withering away of civic education in schools"18 as a possible factor. Corriero and Furdyk, TakingITGlobal's founders, 
Table 2

Interest in the issues-percentage responding "Often"

\begin{tabular}{lll}
\hline & TIG Members & Other Respondents \\
\hline $\begin{array}{l}\text { I use Web sites, online communities, or online tools } \\
\text { (IM, message boards, etc.) to discuss current events or }\end{array}$ & $47.54 \%$ & $40.56 \%$ \\
$\quad$ issues of importance to me with my friends. & & \\
$\begin{array}{l}\text { I make it a priority to stay informed about current } \\
\quad \text { events or issues important to me. }\end{array}$ & $78.95 \%$ & $58.89 \%$ \\
$\begin{array}{l}\text { When I am with my friends, I discuss current events or } \\
\quad \text { issues of importance to me. }\end{array}$ & $60.44 \%$ & $48.33 \%$ \\
\begin{tabular}{l} 
I read news online. \\
\hline
\end{tabular} & $67.74 \%$ & $46.11 \%$ \\
\hline
\end{tabular}

Table 3

Action on the issues-percentage responding "Often"

\begin{tabular}{lll}
\hline & TIG Members & Other Respondents \\
\hline $\begin{array}{l}\text { I attend protests or rallies. } \\
\begin{array}{l}\text { I create media online (podcasts, videos, blogs, etc.) to } \\
\quad \text { get the word out about an issue. }\end{array}\end{array}$ 10.02\% & $5.56 \%$ \\
$\begin{array}{l}\text { I attend events or gatherings aimed at affecting positive } \\
\quad \text { change. }\end{array}$ & $43.12 \%$ & $6.67 \%$ \\
$\begin{array}{l}\text { I participate in online protests. } \\
\text { I vote in elections. }\end{array}$ & $15.45 \%$ & $15.00 \%$ \\
$\begin{array}{l}\text { I contact politicians, governments, or authorities about } \\
\quad \text { issues important to me. }\end{array}$ & $16.64 \%$ & $9.44 \%$ \\
\end{tabular}

offer a different explanation for this low participation rates in other action areas than voting and attending events. They believe there is a disconnect between the available opportunities for engagement and the spaces where young people spend their time. In other words, civic institutions and initiatives are simply not keeping up with the times. ${ }^{19}$

Our survey findings indicated that TakingITGlobal.org's tools were primarily used for three purposes:

- Support and motivation

- Networking and information

- Mobilizing and organizing real-world action

In questions relating to the use of TakingITGlobal.org's tools for these purposes, 40 percent or more of TakingITGlobal.org respondents gave positive responses. They also provided numerous qualitative responses indicating their use of these tools for these three purposes.

\section{Support and Motivation}

Of the 501 TakingITGlobal.org members who responded to the survey:

- $\quad 73.9$ percent agreed that "through my experience with TakingITGlobal, my perception of the ability of youth to affect change in the world has improved;

- $\quad 63.5$ percent agreed that "I have been inspired by a young person I have read about and/or communicated with on the TakingITGlobal site." 
Qualitative responses further confirm that the online presence of a large network of youth leaders is in and of itself a great value to many TakingITGlobal.org members. As we discuss in our landscape survey in the next section, having the right people engaged in an online community is just as important as its functionality. Allan, from the United Kingdom, mentioned that "the key [motivator] was reassurance that there were other people out there trying as well-we are not alone."

\section{Networking and Information}

Beyond finding inspiration, many TakingITGlobal.org members reported finding information and networks to help them take steps toward action:

- $\quad 41.9$ percent of respondents agreed that they "had contacted an organization listed in TakingITGlobal.org's database."

- $\quad 54.1$ percent of respondents agreed that "the site has helped them become more informed about issues important to them."

In their qualitative responses, TIG members mentioned their ability to connect with peers through the site as a key factor in their projects:

I liaised with another TakingITGlobal member to produce a 30-second TV commercial that was shown on the local community cable TV channel and on YouTube. That commercial drove 10,000 people to our non-profit community event and was the key influence in driving 179,000 hits to the Web site.-Ginger, Canada

Some of the young people have been contacting me through TakingITGlobal and we have been connected from that time until now and sometimes it results to a project where we develop program exchanges in 2 countries.-Albert, Rwanda

Clearly, networking and information are some of TIG's key value-adds. The organization operates on the assumption that through the opportunity to connect easily and efficiently with young leaders in their areas of interest, more active members will inspire less active members to take action. This has been a key driver in the organization's decision to work with networks like the Global Youth Coalition on HIV/AIDS. TakingITGlobal.org gives any approved, youth-serving organization the opportunity to quickly, and freely, publicize their work to tens of thousands of daily visitors to TakingITGlobal.org. ${ }^{20}$ This dissemination feature has proven to be of particular benefit to smaller organizations that have less capacity to create their own highly visible Web sites. Members of these smaller organizations can also take advantage of free project pages and mailing lists to organize and mobilize.

\section{Mobilizing and Organizing to Real-World Action}

- 44.1 percent of respondents agreed that "the information, networks, and tools to mobilize and organize found on TakingITGlobal.org have helped them make change in lives or community."

- $\quad 49.5$ percent of respondents indicated that "TakingITGlobal.org had helped them to change something in their own lives."

While this survey has only begun to probe the changes that young people are making in the "real world" using TakingITGlobal.org's tools and online community, many respondents attribute the decision to engage or refocus their engagement projects to their involvement with the site. George, a respondent from Malawi, reported, "One of the very first 
inspirations I got from my involvement with TakingITGlobal was to set up an information centre (www.cridoc.net) on child/youth rights issues in Malawi." Other members had similar stories, ranging from an education campaign around Hepatitis B vaccinations in Ghana to the republication of an article about forced migration in a major Ugandan newspaper.

While these anecdotes are just that, they do provide a positive indication that involvement in TakingITGlobal.org is producing a more engagement-oriented attitude among youth. These findings should not be surprising, given that YouthNoise, a similar site reviewed in the next section, reports similar findings: "Studies have shown that YouthNoise participation has led to a 25 percent increase in volunteering and a 90 percent increase in the global awareness of users from modestly aware to highly aware." ${ }^{21}$

\section{Putting TIG in Context: A Look at Other Sites}

TakingITGlobal.org and the sites we look at in this section all use varying combinations of a standard set of online tools. These tools are used in a variety of contexts for a range of purposes and are all popular with youth. Not only are these tools important for engaging youth on their own terms - they have all been shown to be useful for finding and sharing information, networking with peers and organizing. The Pew Internet Report on Teens and Technology also confirms that American teens are using these tools in other contexts, such as finding health information or socializing. ${ }^{22}$ Table 4 provides a summary of these standard online tools and how they are used in the context of youth civic engagement:

Landscape Survey Methodology The initial results of our youth survey suggest that youth are using TakingITGlobal.org as a source of information and people through its informational tools, resources, and social networking features. They are also using the site to mobilize and organize, which leads to action in their offline communities. Based on these findings, we believe that the most important goals of civic engagement sites should be to facilitate these online activities. With this in mind, we set out to examine the current landscape of online civic engagement and report on best practices and areas for improvement. We hope that this will inform future online civic engagement projects and improving existing ones.

In order to create a snapshot of the current online civic engagement landscape we developed two screens. First, a screen to identify the sites for inclusion in our survey and, second, a screen to tease out the strengths and areas for improvement in the strategies and toolsets of the sites we examined.

To ensure that we examined comparable sites, we established a set of minimum criteria to determine which sites would be included in our survey. Specifically, a social networking or online community site must

- Be aimed at youth, or have a relatively large youth membership

- Have an interactive Web-based social tool at its core that allows members to interact

- Be current and operational (site is accessible and usable)

- Be available in English

- Be aimed at encouraging and supporting positive social change.

Our initial survey universe consisted of twenty-three potential sites. These sites were identified by experts in the field of online civic engagement, links from popular sites, and sites 
Table 4

Standard online tools in the context of civic engagement

\begin{tabular}{|c|c|c|c|c|}
\hline Tool & Description & Networking with peers & Finding and sharing information & Organizing \\
\hline Blogs & $\begin{array}{l}\text { - Journal-style entries } \\
\text { made in reverse } \\
\text { chronological order } \\
\text { - Created by an } \\
\text { individual or group } \\
\text { - Readers can comment } \\
\text { on entries }\end{array}$ & $\begin{array}{l}\text { Blogs say a lot about their } \\
\text { authors. Browsing peers' blogs } \\
\text { makes it easier for youth to } \\
\text { find allies and helpers. }\end{array}$ & $\begin{array}{l}\text { Blogs are a great place to find and } \\
\text { disseminate information. Their } \\
\text { power and reach has been } \\
\text { demonstrated in several } \\
\text { high-profile situations. A survey } \\
\text { respondent from Nigeria observed: } \\
\text { "The discussion boards and blogs } \\
\text { [on TakingITGlobal.org] helped } \\
\text { access people's opinion on diverse } \\
\text { issues." }\end{array}$ & $\begin{array}{l}\text { Group blogs are a good } \\
\text { collaboration tool for small } \\
\text { groups. Members can share } \\
\text { updates and launch } \\
\text { discussions. Successful larger } \\
\text { group blogs exist on } \\
\text { LiveJournal, where members } \\
\text { organically organize around }^{\text {specific topics. }}{ }^{\text {a }}\end{array}$ \\
\hline $\begin{array}{l}\text { Discussion } \\
\text { Forums }\end{array}$ & $\begin{array}{l}\text { - A centralized } \\
\text { collection of } \\
\text { conversation threads } \\
\text { - Often moderated to } \\
\text { some degree } \\
\text { - Members can start new } \\
\text { or reply to existing } \\
\text { threads }\end{array}$ & $\begin{array}{l}\text { Youth can use forums to find: } \\
\text { - Support } \\
\text { - Feedback } \\
\text { - Volunteers for an initiative }\end{array}$ & $\begin{array}{l}\text { Posting links or information to } \\
\text { popular discussion boards is a good } \\
\text { way to promote an issue. }\end{array}$ & $\begin{array}{l}\text { Not very good for organizing } \\
\text { as it is a public space used } \\
\text { by many people - akin to } \\
\text { holding a meeting in the } \\
\text { middle of a party. }\end{array}$ \\
\hline $\begin{array}{l}\text { Web } \\
\text { messaging }\end{array}$ & $\begin{array}{l}\text { - Members can send } \\
\text { private text messages } \\
\text { to other members of } \\
\text { the same site }\end{array}$ & $\begin{array}{l}\text { A simple way to converse with a } \\
\text { peer who might assist with a } \\
\text { project. It also provides an } \\
\text { easy entry point to the } \\
\text { community. A survey of } \\
\text { respondents from Australia } \\
\text { reported: } \\
\text { "TakingITGlobal.org instant } \\
\text { messenger really helped me } \\
\text { make the transition from } \\
\text { Web site user to community } \\
\text { member." }\end{array}$ & $\begin{array}{l}\text { Web messaging can be used to send } \\
\text { information to one person at a } \\
\text { time, making it useful for targeted } \\
\text { messages. }\end{array}$ & $\begin{array}{l}\text { Good for organizing a small } \\
\text { group, but as it is designed } \\
\text { for one-to-one } \\
\text { communication its use is } \\
\text { limited. }\end{array}$ \\
\hline
\end{tabular}


Table 4

Standard online tools in the context of civic engagement (Continued)

\begin{tabular}{|c|c|c|c|c|}
\hline Tool & Description & Networking with peers & Finding and sharing information & Organizing \\
\hline $\begin{array}{l}\text { Social } \\
\text { networking } \\
\text { tools }\end{array}$ & $\begin{array}{l}\text { - Members create public } \\
\text { profiles; contents } \\
\text { vary by site } \\
\text { - Standard details } \\
\text { include personal and } \\
\text { contact information, } \\
\text { photos, location, etc. } \\
\text { Some services show } \\
\text { recently created } \\
\text { content. } \\
\text { - Members can list their } \\
\text { friends. This list is } \\
\text { public and } \\
\text { browse-able. } \\
\text { - Members can often } \\
\text { leave comments, } \\
\text { which are shown } \\
\text { publicly on a profile. }\end{array}$ & $\begin{array}{l}\text { Public profiles make it easy for } \\
\text { youth to learn each other's } \\
\text { interests and goals. Youth can } \\
\text { also browse other's friend } \\
\text { networks, increasing the } \\
\text { number of other people they } \\
\text { can connect with. } \\
\text { Respondents to our survey } \\
\text { mentioned that the profile } \\
\text { page on TakingITGlobal.org } \\
\text { was the way they found out } \\
\text { about another member with } \\
\text { whom they later collaborated. }\end{array}$ & $\begin{array}{l}\text { Youth can post links or information } \\
\text { about issues, current events, or } \\
\text { ways to get involved on their } \\
\text { profiles. Other youth are more } \\
\text { likely to get involved or take action } \\
\text { if they find out about something } \\
\text { from a friend. }\end{array}$ & $\begin{array}{l}\text { Youth can mobilize their } \\
\text { networks of friends through } \\
\text { their profiles. The efficacy of } \\
\text { this was demonstrated in } \\
\text { 2006, when American youth } \\
\text { used their MySpace profiles } \\
\text { to organize a countrywide } \\
\text { walkout in protest of new }_{\text {immigration laws. }}^{\text {b }}\end{array}$ \\
\hline
\end{tabular}

${ }^{a}$ K. Raynes-Goldie, Pulling Sense out of Today's Informational Chaos: LiveJournal as a Site of Knowledge Creation and Sharing, First Monday 9 , no. 12 (2004), http://www.firstmonday.org/issues/issue9_12/raynes/index.html (retrieved January 8, 2007).

${ }^{b}$ d. boyd, Identity Production in a Networked Culture: Why Youth $\bullet$ MySpace, American Association for the Advancement of Science, St. Louis, MO, February 19, 2006, http://www.danah.org/papers/AAAS2006.html (retrieved January 8, 2007). 
examined in other surveys. ${ }^{23}$ We examined each one by signing up and systematically trying each feature. Out of the twenty-three sites, only six met our minimum criteria to be included in our survey. The top two reasons for exclusion in our survey were that the site was no longer operational or that the site did not include an interactive social component and was simply a static Web page. The six sites we surveyed were YouthNoise, CampusActivism, UNICEF Voices of Youth, ${ }^{24}$ Youth Action Net, Zaadz, and BattleCry. ${ }^{25}$ We also included TakingITGlobal.org, which we more thoroughly analyzed in the previous section.

Because there is currently no established methodology for evaluating online civic engagement sites, we adapted a survey methodology from an online community evaluation framework created by Clarisse De Souza and Jenny Preece. ${ }^{26}$ De Souza and Preece define communities and social networks as combinations of two key elements: technology (usability) and sociability (policy, purpose, and people). Blogger Sarah Pullman noted the same element in her analysis of Zaadz: "there are two things that determine the value of social networking tools: (1) the functionality of the tools themselves, and what they allow people to do, and (2) the people who are using the service." ${ }^{27}$ Having the most sophisticated and easy-to-use online community platform does not guarantee success, nor does having access to a large number of members. A site has to be relatively usable and have appealing technology so that people can easily accomplish their goals, just as it has to have a critical mass of the right kind of users. If the tools are frustrating, or there are very few members, a site is not likely to be used. As MySpace demonstrates, successful online communities do not necessarily have to be the best designed, but at least have the right people.

The functionality and type of tools on a site matter for two reasons. First, the site has to have tools that are appealing, familiar, and useful enough so that youth will use them. Second, the site has to facilitate activities that help youth reach their civic engagement goals. These activities, as we found in our youth survey, are finding the right information, organizing, networking, and collaborating. For this reason, we examined not only what types of tools were on the sites examined (profiles, blogs, tags, and so on) but also how sophisticated those tools were. For example, the blogging tools across the sites we examined varied greatly in terms of features and functionality and thus their appeal, familiarity, and usefulness to youth.

We also kept in mind the influence of commercial services. Although not aimed at civic engagement, MySpace and Facebook set the tone and expectations for many youth (especially those in developed countries). If these expectations are not met, they are not likely to use or keep using a site. Keeping all this in mind, we based our survey on three key areas: usability, people, and purpose and policy.

In usability, we looked at technology and design issues, such as

- What tools are used and how

- $\quad$ Ease of use

- Level of interactivity

- Level of maintenance.

With people, we were concerned with

- $\quad$ Size of membership

- Demographics of the members 
- $\quad$ Languages spoken by membership.

In purpose and policy, we were interested in

- $\quad$ Funding

- Who runs the site

- The openness of the community

- $\quad$ Rules and moderation

- $\quad$ Focus and purpose of site.

Overview of Web Sites Reviewed

In Table 5, we summarize the history and key features of the seven sites we reviewed in depth.

Landscape Survey Findings Usability Despite vast differences in the tools offered by the sites surveyed, five of the seven had discussion forums. Forums were the primary means of communication on UNICEF Voice of Youth and Youth Action Network, while the others used a suite of communication tools including forums. Forums are among the oldest communication styles online, and operate in a manner similar to e-mail lists, which are popular in low-connectivity situations. As a result, discussion forums are more familiar and accessible to youth with limited connectivity. Sites that only offer discussion forums may however discourage youth with more sophisticated Internet literacy, as this group expects the latest innovations from the sites they use. Anything less may inadvertently imply that the site's makers "don't get it." The two sites with the most members (TakingITGlobal.org and YouthNoise) offered multiple modes of communication to members. This way, few users are directly excluded, and youth have access to the tools they are most familiar with.

Only two of seven sites featured formal collaboration tools to help youth organize around their goals. TakingITGlobal.org and YouthNoise both offer project pages that allow groups to publicize and coordinate their projects, using mailing lists and a shared online workspace. Youth Action Net offers project pages for displaying information, but does not provide collaboration features.

Problems with site design and usability were common. Many sites deviated from the standard conventions of usability as recommended by experts such as Steven Krug. ${ }^{28}$ Navigation and findability were-in varying degrees-a challenge. On YouthNoise, for example, the navigation menu, visual queues and naming conventions all change from one part of the site to the next, which can be confusing for users. We noticed a similar problem with Youth Action Net, whose navigation menu inconsistently featured a prominent yet broken link to an essay contest. The navigation menu also appears on the left side of the front page, even though it is oriented on the right side everywhere else. Usability was also a problem for TakingITGlobal. In our youth survey, a number of TakingITGlobal members mentioned that the site was becoming overwhelming. Getting an idea of the goals or features of many of the sites was not easy, with most sites offering a complicated and jargon-filled mission statement to inform. These design and usability issues can not only harm a site's image but, more important, can make it harder for youth to find the necessary information and people to affect change in their communities. If a site is too difficult to use, less savvy Internet users will be discouraged and potentially excluded. 
Table 5

Summary of basic site information and features

\begin{tabular}{|c|c|c|c|}
\hline Site & Mandate and distinguishing features & Tools & Year launched and project details \\
\hline $\begin{array}{l}\text { Activism Network } \\
\text { activismnetwork.org }\end{array}$ & $\begin{array}{l}\text { The Activism Network is essentially an } \\
\text { interactive database of activists, } \\
\text { activist organizations, and events } \\
\text { provided to facilitate networking and } \\
\text { communication for those involved in } \\
\text { activist causes. } \\
\text { The goal of the Activism Network is to } \\
\text { "strengthen progressive social } \\
\text { movements around the world } \\
\text { through the sharing of contacts, } \\
\text { event information, ideas and } \\
\text { resources." } \\
\text { A large part of the site's mandate is to } \\
\text { provide connections and the } \\
\text { resources that groups and individuals } \\
\text { need for their offline events and } \\
\text { initiatives. }\end{array}$ & $\begin{array}{l}\text { - Searchable directories and lists (events, } \\
\text { email lists, resources, campaigns, } \\
\text { contacts etc.). Members can add } \\
\text { items to any list } \\
\text { - Simple profiles of members with } \\
\text { contact information, issues of interest } \\
\text { and campaign involvement }\end{array}$ & $\begin{array}{l}2002 \\
\text { Size (as of January 2007) } \\
3700 \\
\text { Demographic } \\
\text { Originally for college- and } \\
\text { university-aged activists in North } \\
\text { America, now for everyone. } \\
\text { Language(s) } \\
\text { English } \\
\text { Platform } \\
\text { Custom open source. Currently being } \\
\text { ported to Drupal. } \\
\text { Creator/Funder } \\
\text { Aaron Krieder, who also funds the } \\
\text { project with his own time and } \\
\text { money. Additional revenue generated } \\
\text { by Google Adsense }\end{array}$ \\
\hline $\begin{array}{l}\text { BattleCry } \\
\text { www.battlecry.com }\end{array}$ & $\begin{array}{l}\text { BattleCry is a social networking site and } \\
\text { resource "for Christian teens, } \\
\text { churches, youth groups, and leaders." } \\
\text { The site was also dubbed as the } \\
\text { "Christian alternative to Myspace" } \\
\text { and the site featured the tagline "Let } \\
\text { MySpace be His space."b } \\
\text { Battlecry.com is part of a larger and } \\
\text { older initiative by Teen Mania of } \\
\text { offline stadium events, gatherings } \\
\text { and demonstrations which use the } \\
\text { BattleCry brand.c The offline } \\
\text { activities are heavily promoted on the } \\
\text { site. }\end{array}$ & $\begin{array}{l}\text { - Basic blogging functionality } \\
\text { - Social networking tools (profiles, } \\
\text { ability to list friends, ability to leave } \\
\text { messages on other people's profiles) } \\
\text { - Resource section with videos, } \\
\text { documents, and guides to help youth } \\
\text { spread the word about their } \\
\text { movement } \\
\text { - Discussion forums at } \\
\text { forums.battlecry.com, which were } \\
\text { locked in May } 2006 \text { and new posts } \\
\text { were disallowed. } \\
\text { - Task progress tools. }\end{array}$ & $\begin{array}{l}\text { Early } 2006 \\
\text { Size (as of January 2007) } \\
\text { 36,000 members (according to user } \\
\text { profiles page-http://www.battlecry. } \\
\text { com/x_search.php) } \\
\text { Demographic } \\
\text { Primarily American Christian } \\
\text { (Evangelical) youth, some Canadian } \\
\text { members } \\
\text { Language(s) } \\
\text { English } \\
\text { Platform } \\
\text { Custom closed source solution } \\
\text { Creator/Funder } \\
\text { Teen Mania Ministries }\end{array}$ \\
\hline
\end{tabular}


Table 5

Summary of basic site information and features (Continued)

\begin{tabular}{|c|c|c|c|}
\hline Site & Mandate and distinguishing features & Tools & Year launched and project details \\
\hline & $\begin{array}{l}\text { BattleCry is the only site we looked at } \\
\text { that had created a tool based on } \\
\text { offline action. Members are given a } \\
\text { set list of tasks (such as praying more } \\
\text { often) that they can complete to } \\
\text { further the goals of the initiative. The } \\
\text { progress of these tasks are shown on a } \\
\text { member's profile for other members } \\
\text { to see and be inspired by. }\end{array}$ & & \\
\hline $\begin{array}{l}\text { Youth Action Net } \\
\text { youthaction- } \\
\text { net.org }\end{array}$ & $\begin{array}{l}\text { Youth Action Net is an interactive } \\
\text { webpage with resources and a } \\
\text { discussion forum. } \\
\text { According to their site, } \\
\text { "YouthActionNet is a program that } \\
\text { invests in the power and promise of } \\
\text { young people to create positive } \\
\text { change. Through its dynamic Web } \\
\text { site, awards, customized training } \\
\text { programs, and peer-to-peer learning } \\
\text { opportunities, YouthActionNet offers } \\
\text { young change makers ideas, } \\
\text { resources, and connections to like } \\
\text { minds around the world." }\end{array}$ & $\begin{array}{l}\text { - Simple static Web page building tools } \\
\text { (personal and project pages) } \\
\text { - Discussion forums } \\
\text { - Information and resource section } \\
\text { - Opportunities database that members } \\
\quad \text { can add items to }\end{array}$ & $\begin{array}{l}2001 \\
\text { Size (as of January 2007) } \\
290 \text { members' Web pages and } 371 \\
\text { member project pages. } \\
\text { Note: this number has not changed } \\
\text { since October } 2006 \\
\text { Demographic } \\
\text { Global youth } \\
\text { Language(s) } \\
\text { English } \\
\text { Platform } \\
\text { Closed custom solution } \\
\text { Creator/Funder } \\
\text { International Youth Foundation. } \\
\text { Funded by Nokia }\end{array}$ \\
\hline $\begin{array}{l}\text { TakingITGlobal } \\
\text { takingitglobal.org }\end{array}$ & $\begin{array}{l}\text { TakingITGlobal is an online } \\
\text { community with social networking } \\
\text { features aimed at providing a virtual } \\
\text { space for cross cultural } \\
\text { understanding, expression, dialogue } \\
\text { and collaboration among youth. }\end{array}$ & $\begin{array}{l}\text { - Social networking tools (profiles, } \\
\text { ability to list friends) } \\
\text { - Customizable blogs (individual and } \\
\text { group) }\end{array}$ & $\begin{array}{l}2000 \\
\text { Size (as of January 2007) } \\
130,000 \\
\text { Demographic } \\
\text { Global youth }\end{array}$ \\
\hline
\end{tabular}


Table 5

Summary of basic site information and features (Continued)

\begin{tabular}{|c|c|c|c|}
\hline Site & Mandate and distinguishing features & Tools & Year launched and project details \\
\hline & $\begin{array}{l}\text { TakingITGlobal also runs many offline } \\
\text { programs which are strongly } \\
\text { integrated with the Web site, online } \\
\text { tools and site members. }\end{array}$ & $\begin{array}{l}\text { - Discussion forums } \\
\text { - Searchable events, organization and } \\
\text { opportunities database where } \\
\text { members can add to } \\
\text { - Resource and information sections } \\
\text { - Simple image galleries } \\
\text { - Podcasting tools } \\
\text { - Web messenger (TIG messenger) } \\
\text { - Interactive collaboration tools (mailing } \\
\text { lists, project workspaces etc.) }\end{array}$ & $\begin{array}{l}\text { Language(s) } \\
\text { English, French, Spanish, Russian, } \\
\text { Dutch, Italian, Portuguese, } \\
\text { Romanian, Turkish, Chinese, and } \\
\text { Arabic } \\
\text { Platform } \\
\text { Closed custom solution } \\
\text { Creator/Funder } \\
\text { TakingITGlobal } \\
\text { Funded by various corporate and NGO } \\
\quad \text { donations and partnerships. }\end{array}$ \\
\hline $\begin{array}{l}\text { YouthNoise } \\
\text { youthnoise.org }\end{array}$ & $\begin{array}{l}\text { YouthNoise is an online community } \\
\text { with social networking features that } \\
\text { is designed as "a place for teens to } \\
\text { talk about various issues, raise money } \\
\text { for different causes, and many other } \\
\text { things. The issues discussed range } \\
\text { from economy, government, } \\
\text { education, animal rights, tolerance, } \\
\text { media, environment, health, poverty, } \\
\text { war, peace, violence, spirituality, and } \\
\text { more." } \\
\text { The mission of YouthNoise is "to } \\
\text { inspire and empower young people } \\
\text { everywhere to catapult their passion } \\
\text { and idealism into movements to } \\
\text { sustain the planet."f }\end{array}$ & $\begin{array}{l}\text { - Discussion forums } \\
\text { - Social networking tools (profiles, } \\
\text { ability to list friends) } \\
\text { - Basic blogging functionality (built into } \\
\text { profile page) } \\
\text { - Collaboration tools (project page with } \\
\text { project information and members } \\
\text { involved) } \\
\text { - Information and Resource Section } \\
\text { - Videoblogging tools (through } \\
\text { veeker.com) } \\
\text { - Legislative Action Centre (interactive } \\
\text { tools to find and contact elected } \\
\text { officials in the United States) }\end{array}$ & $\begin{array}{l}2001 \\
\text { Size (as of January 2007) } \\
113,000 \\
\text { Demographic } \\
\text { Originally aimed at American Youth, } \\
\text { recently refocused to global youth } \\
\text { audience. } \\
\text { Language(s) } \\
\text { English } \\
\text { Platform } \\
\text { Closed custom solution } \\
\text { Creator/Funder } \\
\text { Save The Children, now spun off as } \\
\text { own entity. Funded by various } \\
\text { corporate and NGO donations and } \\
\text { partnerships. }\end{array}$ \\
\hline $\begin{array}{l}\text { UNICEF Voices } \\
\text { of Youth } \\
\text { unicef.org/voy/ }\end{array}$ & $\begin{array}{l}\text { Voices of Youth is a Web site with a } \\
\text { discussion forum at its core. }\end{array}$ & $\begin{array}{l}\text { - Information and Resource Section } \\
\text { - Discussion forums } \\
\text { - Chat }\end{array}$ & $\begin{array}{l}1995 \\
\text { Size (as of January 2007) } \\
20,000\end{array}$ \\
\hline
\end{tabular}


Table 5

Summary of basic site information and features (Continued)

\begin{tabular}{|c|c|c|c|}
\hline Site & Mandate and distinguishing features & Tools & Year launched and project details \\
\hline & $\begin{array}{l}\text { Voices of Youth was originally founded } \\
\text { in } 1995 \text { so that youth around the } \\
\text { world could send messages to world } \\
\text { leaders at the World Summit for } \\
\text { Social Development which was held } \\
\text { that year in Copenhagen. } .^{g} \text { Today, the } \\
\text { goal of the site is "To offer all children } \\
\text { and adolescents, including the } \\
\text { hard-to-reach, a safe and supportive } \\
\text { global cyberspace within which they } \\
\text { can explore, discuss, and partner on } \\
\text { issues related to human rights and } \\
\text { social change, as well as develop their } \\
\text { awareness, leadership, community } \\
\text { building, and critical thinking skills } \\
\text { through active and substantive } \\
\text { participation with their peers and } \\
\text { with decision makers globally."h }\end{array}$ & & $\begin{array}{l}\text { Demographic } \\
\text { Global children and youth, with an } \\
\text { emphasis on children and youth in } \\
\text { developing countries } \\
\text { Language(s) } \\
\text { English, French, Spanish, Arabic } \\
\text { Platform } \\
\text { Closed custom solution } \\
\text { Creator/Funder } \\
\text { UNICEF }\end{array}$ \\
\hline $\begin{array}{l}\text { Zaadz } \\
\quad \text { zaadz.com }\end{array}$ & $\begin{array}{l}\text { Described by critics as a being a site for } \\
\text { "new agey, hippie, tree-hugging } \\
\text { freaks,"i Zaadz is a social networking } \\
\text { site with the aim of helping people to } \\
\text { "change the world" though } \\
\text { spirituality and "conscious } \\
\text { capitalism." } \\
\text { The Zaadz mission statement: "We're } \\
\text { gonna change the world. Our math } \\
\text { goes like this: you be the change }+ \\
\text { you follow your bliss + you give your } \\
\text { greatest strengths to the world } \\
\text { moment to moment to moment + we } \\
\text { do everything in our power to help }\end{array}$ & $\begin{array}{l}\text { - Podcasting tools } \\
\text { - Basic blogging tools } \\
\text { - Discussion forums } \\
\text { - Sophisticated social networking tools } \\
\text { (profiles, ability to list friends, and } \\
\text { ability to find, create, and join } \\
\text { groups) } \\
\text { - Searchable database of books, events, } \\
\text { businesses, and quotes that members } \\
\text { can add to } \\
\text { - Tagging and tag clouds }\end{array}$ & $\begin{array}{l}2006 \\
\text { Size (as of July 2006) } \\
33,000 \\
\text { Demographic } \\
\text { "Spiritual activists"—not necessarily } \\
\text { aimed youth, but site has large } \\
\text { membership of youth (20\% of } \\
\text { members are aged } 18-25 \text { and } 37 \% \\
\text { aged } 26-35 . \text { Only } 1 \% \text { of members, } \\
\text { however, were under } 18 \text { ). }\end{array}$ \\
\hline
\end{tabular}

could send messages to world

leaders at the World Summit for

the ${ }^{g}$ Today, the

of the site is "To offer all children

and adolescents, including the

explore, discuss, and partner on

sues related to human rights and

a ciar change, as well as develop their

building, and critical thinking skills

through active and substantive

participation with their peers an

with decision makers globally."

critics as a being a site for

"new agey, hippie, tree-hugging

, Zaadz is a social networking

"change the world" though

spirituality and "conscious

oment to moment to moment + we

do everything in our power to help 
Table 5

Summary of basic site information and features (Continued)

\begin{tabular}{|c|c|c|}
\hline Site & Mandate and distinguishing features & Year launched and project details \\
\hline & $\begin{array}{l}\text { you succeed + you inspire and } \\
\text { empower everyone you know to do } \\
\text { the same + we team up with millions } \\
\text { like us = we just affected billions = } \\
\text { we (together) changed the world."' } \\
\text { Unlike the other sites we looked at, } \\
\text { Zaadz is entirely a social utility like } \\
\text { Facebook and as such, has no } \\
\text { significant static informational or } \\
\text { resource components. In other words, } \\
\text { Zaadz is more like an application } \\
\text { than a Web page because it is more } \\
\text { interactive than all the other sites we } \\
\text { have examined. } \\
\text { Zaadz was the only site we looked that } \\
\text { is for profit. It was also the most } \\
\text { sophisticated and well designed of all } \\
\text { the sites and the only one to use } \\
\text { AJAX, a new programming technique } \\
\text { that makes Web sites act more like } \\
\text { applications than static web pages. }\end{array}$ & $\begin{array}{l}\text { Language(s) } \\
\text { English } \\
\text { Platform } \\
\text { Closed custom solution } \\
\text { Creator/Funder } \\
\text { Brian Johnson and Aaron Eisenberger. } \\
\quad \text { Zaadz is for profit. }\end{array}$ \\
\hline
\end{tabular}
applications than static web pages.

a Activism Network, Our Project, n.d., http://www.activismnetwork.org/ourproject.html (retrieved January 8, 2007).

bWikipedia, BattleCry: Programs, Activities and Methods, 2006, http://en.wikipedia.org/wiki/Battle_Cry_Campaign\#Programs.2C_activities_and_methods (retrieved January 8, 2007).

'J. DeFao, Evangelical Christian Concert Draws 25,000, San Francisco Chronicle, March 26, 2006, http://www.sfgate.com/cgi-bin/article.cgi?f=/ c/a/2006/03/26/BAGRLHUDM81.DTL (retrieved January 8, 2007).

dYouthActionNet.org, Who We Are, 2004, http://www.youthactionnet.org/who (retrieved January 8, 2007).

'YouthNoise, Wikipedia, 2006, http://en.wikipedia.org/wiki/Youth_Noise (retrieved October 15, 2006).

${ }^{f}$ YouthNoise, About YouthNoise, 2006, http://www.youthnoise.org/page.php?page_id=2312 (retrieved January 8, 2007).

gUNICEF, Voices of Youth: About This Site, n.d., http://www.unicef.org/voy/about/about_261.html (accessed January 8, 2007).

${ }^{h}$ UNICEF. Voices of Youth: About This Site, Mission Statement, n.d., http://www.unicef.org./voy/about/about_255.html (retrieved January 8, 2007).

${ }^{\mathrm{i}}$ Coolmel, C4Chaos: B-Scan with Brian Johnson (a.k.a. CEO+Philosopher of Zaadz), 2006, http://coolmel.typepad.com/iblog/2006/02/bscan_with_bria. html (retrieved January 8, 2007).

'Zaadz, "Zaadz: Connect. Grow. Inspire. Empower," 2006, http://www.zaadz.com (retrieved January 8, 2007). 
We noticed maintenance issues on some sites. Like other software, Web sites often break due to updates, bugs, hacking, spam, or other user interventions. Even outgoing links must be updated regularly to avoid broken links, a common problem among the sites reviewed. While broken links are annoying, lack of proper site maintenance can prevent youth from getting involved entirely. We received an error when trying to sign up with UNICEF Voices of Youth, which prevented us from proceeding, and an e-mail to the technical support address went unanswered. This sort of experience can be frustrating for users and can cause them to lose interest or avoid the site in the future.

Ensuring that the systems behind a site are running smoothly is vital. Many of the sites we surveyed have implemented some degree of moderation. For example, Youth Action Net requires approval for member-created Web and project pages. Our submission to the Youth Action Net was still unapproved after four months, and the overall number of project and member pages listed had not changed during that time either, indicating a problem in the process. In this case, a lack of maintenance actually prevents members from using a core feature of the site. As we discuss in the next section on key learnings, these maintenance problems relate to issues of sustainability and funding, common challenges for NGOs.

The only sites free of these particular problems were Zaadz and BattleCry, both of which appear well funded. The former is the for-profit creation of two successful entrepreneurs ${ }^{29}$ and the latter is operated by a large evangelical parachurch organization, with an in-house marketing department and guidance from top interactive advertising agency Tocquigny. ${ }^{30}$ Also, BattleCry and Zaadz were created in the past year, whereas the rest emerged between 1995 and 2002, an entirely different era of Web design and functionality.

Purpose, Policy, and People All of the sites we examined focused on civic engagement, community involvement and improvement, or activism. Within that lens, a wide spectrum of purposes emerged. BattleCry aims primarily at recruiting American youth to Evangelical Christianity. UNICEF Voices of Youth aims to give a voice to underserved children and teens around the world and provide rights education. Zaadz, a social-networking site for "spiritual activists," is not explicitly youth-focused, but the majority of its members are aged eighteen to thirty-five.

Despite the range of audiences and goals, five of the seven sites use a very similar strategy to engage and empower youth: a focus on providing information and facilitating connections and networking. Similarly, almost all the sites connected their online tools with offline action-some, such as Youth Action Net or TIG, with very explicit offline programs. This aligns with the initial findings of our youth survey, that youth use online tools to get what they need to make change offline: information, people, and organizing.

The exceptions were BattleCry and Zaadz, both of which use slightly different strategies than the remainder of the group. Zaadz has no static resource sections, unlike the other sites examined, nor does it make a clear connection between online tools and offline action. Rather, it is a sophisticated social-networking tool focused solely on helping people find and connect with each other. Beyond that, its strategy to help its members make positive change is unclear.

BattleCry stands out for an entirely different reason. BattleCry, like Zaadz, is primarily a social-networking site and less an informational resource. However, the similarities between the two sites stop there. Zaadz, and the other sites we examined, facilitated and encouraged bottom-up organic organization and communication among their members, focusing on 
enabling and guiding youth. Using Coleman's terminology from the following chapter, they are all examples of relatively autonomous citizenship. BattleCry, in contrast, took a very topdown or managed approach with a focus on instructing youth. The site's suggested strategies for individual and community improvement reflected this methodology, as did the tools it provided. The strategies are rigid and narrow, with little room for interpretation. The same is true of the site's tools: BattleCry only allows one-to-one or small group communication between members. The only group functionality is linked to church membership, and each member is limited to association with one church, limiting any individual's potential reach. The only one-to-many communication tool on BattleCry was a discussion forum, which was locked shortly after the site launched in 2006.

BattleCry is the only site that has created an online tool to direct and measure offline action. The tool allows members to list their "warrior disciplines" and "battle tactics" on their profiles, with a meter indicating their progress. Examples of the predetermined options include "I will recommit to be submissive to my parents" and "I will read BattleCry for My Generation [a book published by BattleCry itself] and give it to others in my youth group to read." While innovative, the tool fits with the rigidity of the site.

The number of members on the sites varied greatly. The most populated sites, TakingITGlobal and YouthNoise, each had well over 100,000 members, while the least populated, the Activism Network and Youth Action Net, had 3700 members and 400 member pages, respectively. ${ }^{31}$ While TakingITGlobal and YouthNoise both have large memberships, when considered in relation to MySpace (which hit the 100-million membership mark in late 2006), it is evident that the online civic engagement space still has a largely untapped potential audience. $^{32}$

Part of our criteria for inclusion in the survey was the availability of the site in English, so it was no surprise to find that most of the members of the sites we examined were English speakers. It is notable, however, that there are very few multilingual civic engagement or activist sites. Only two of the sites we examined (including those not included in the final survey) were available in multiple languages; the rest were only in English. TakingITGlobal is available in eleven languages and UNICEF Voices of Youth in four. This lack of linguistic diversity restricts the accessibility of these sites for many youth globally, and even in North America, where languages other than English are spoken.

Despite these overarching similarities, we noticed a great deal of difference among users, no doubt the result of the differing purposes of each site. BattleCry consists of American Christian youth, while UNICEF Voices of Youth caters to underserved children and teens from around the globe. Zaadz, aimed at a very specific crowd of "spiritual activists" has a large number of young members, but only 1 percent are under eighteen.

\section{Learnings and Improvements}

The results of our landscape survey can be summarized as follows:

- Most sites had maintenance, design, and/or usability issues, which made them less accessible and appealing for youth

- All the sites but one were nonprofit and NGO-run, and relied primarily on donations, volunteers, or sponsorships for their funding

- $\quad$ Robust and sophisticated collaboration tools were lacking 
- Within the overarching goals of engaging and empowering youth by providing them with information and networking with their peers, there was still a diversity of purposes, policies and members

- Very few sites are offered in multiple languages

- $\quad$ There was a range of membership levels

\section{Sustainability}

Given the problems we identified with site maintenance, design, and usability, funding and sustainability is clearly a challenge for all the sites surveyed. Dynamic Web sites are like plants: they need nurturing and care. Deliberate and ongoing care is even more important considering the high expectations created by well-funded and maintained commercial sites. Therefore, the people and organizations behind online activist, community, and civic engagement sites must develop revenue streams to ensure their sites receive appropriate support and maintenance.

LiveJournal presents an interesting alternative solution. LiveJournal is a large community blogging site popular with youth, founded by early blogger Brad Fitzpatrick while he was still in college. Before Six Apart purchased it in early 2005, LiveJournal was supported by a large group of volunteer members who provided technical and community support as well as technical development. Member suggestions for improvements and features also factored heavily into the development of the site. By involving their members in the day-to-day management of the site, LiveJournal not only created a large, strong, and loyal membership but was also able to stretch their minimal resources. Compared to the sites we examined in our landscape survey, LiveJournal has had very few maintenance, usability, or design issues. Although LiveJournal is not focused on civic or community engagement, it has nonetheless empowered and engaged many of its young users in a meaningful way, and has given them the ability to influence the development of their online community. Unfortunately, the involvement of the community has diminished since Six Apart took control of LiveJournal and brought in more paid staff. ${ }^{33}$

LiveJournal is the only example we have seen of members being so heavily involved in the day-to-day operations of an online community. We contrast this with BattleCry, a site that had almost no member input or involvement. Activist, community, and civic engagement sites could benefit greatly from involving their members as LiveJournal has. They could potentially increase their membership by providing better tools and features to facilitate networking and information access, and by creating a sense of ownership and loyalty. Creating better tools and increasing membership is not only good for the organizations, but good for youth as well. The greater youth's access to people, information, and organizational tools, the easier it is to accomplish civic engagement or community improvement goals.

Tools

Almost across the board we observed usability and design issues, and a lack of robust collaborative tools. None of the sites we examined, except for the well-funded Zaadz and BattleCry, met the level of sophistication or usability of their commercial counterparts. It is vital that sites keep up with the state of the art set by commercial sites to ensure that youth are engaged in a way that is not only appealing but also highly effective. TakingITGlobal benefits from having multiple in-house staff members dedicated to 
technology development. YouthNoise, and to a lesser extent BattleCry, have both begun to take resource-saving measures to keep up with the latest Internet trends. YouthNoise has begun to feature embedded videos about current events and issues from the popular video sharing site, YouTube, on its front page. BattleCry now asks members for submissions via YouTube and provides banners that members can include on their MySpace profiles. This sort of integration with commercial services allows sites to easily add new features for their members, while also reaching out to youth who are sole users of commercial services.

\section{Languages}

Despite the global mandate of several of the sites we examined (including those not included in our final landscape survey), only two were available in more than one language. Given an increasingly global world, it is important for activist, civic, and community engagement sites to provide access in multiple languages, especially in countries with more than one official language. In so doing, these sites will be better able to provide youth with access to their peers in their most comfortable and functional linguistic environment. The importance of having the right people using a site was demonstrated by the success of MySpace-youth want to be where their friends are. Increasing the number of languages will not only increase membership but also help youth find the people they need to connect with to make the change they want in their communities.

Translating a site into other languages can be a good way of getting youth directly engaged with a site. TakingITGlobal was able to translate its site into eleven languages largely because of the help of volunteer members. In many cases, these translation volunteers have also taken on the role of promoting the site to build a local audience and locally relevant content. TakingITGlobal has been successful in reaching a global audience and has the largest membership of all the sites we examined. LiveJournal used the same strategy for their site translation, and as a result, has become a very popular blogging site in Russia (their second-largest member base after the United States is Russia). ${ }^{34}$

\section{Conclusion}

Throughout this chapter, we have presented examples and possibilities of a growing movement of youth who inform and organize themselves online, and then proceed to take action in their communities. We have also seen a growing movement of interactive online civic engagement sites based around social tools, such as TakingITGlobal.org, aimed at facilitating youth engagement by providing access to peers, information and tools to mobilize and organize. Yet, just like the movement, the research and feedback mechanisms are young and in need of further development.

The most burning research question revolves around the development of an evaluation methodology that assesses the efficacy of online civic engagement sites, specifically the connection between online and offline preparation and action. We recommend further exploration of the initial findings from our youth survey: specifically more detailed investigations into the use and potential improvements to online civic engagement sites for networking with peers, finding information, and organizing.

We are excited about the potential of well-executed online civic engagement sites. When youth are engaged on their own terms, we strongly believe that the future of young people and positive change in the world will be bright. 


\section{Notes}

1. Amanda Lenhart, Mary Madden, and Paul Hitlin, Teens and Technology: Youth Are Leading the Transition to a Fully Wired and Mobile Nation, Pew Internet, 2005, http://www.pewinternet.org/ report_display.asp?r=162 (retrieved January 8, 2007).

2. Joseph Hall, Jimmy Wales' Talk at SIMS, Not Quite a Blog 2.0, 2006, http://josephhall.org/nqb2/ index.php/2005/11/03/jimbo (retrieved January 8, 2007).

3. Michael Delli Carpini, Gen.Com: Youth, Civic Engagement and the New Information Environment, Political Communication 17 (2000): 341-49.

4. Ayla Khosroshahi, Jennifer Corriero, Svetlana Taraban, Sarah Richardson, Franziska Seel, and Clarisse Kehler Siebert, TakingITGlobal, 2006, Cross Canada Mapping of Youth-led and/or Highly-engaged Initiatives: Final Report, http://about.takingitglobal.org/d/publications?view=17 (retrieved January 8, 2007).

5. danah boyd, Friends, Friendsters and Top 8: Writing Community Into Being on Social Network Sites, First Monday 11, no. 12 (2006), http://www.firstmonday.org/issues/issue11_12/boyd/index.html (retrieved January 8, 2007).

6. danah boyd, Identity Production in a Networked Culture: Why Youth $\bullet$ MySpace, American Association for the Advancement of Science, St. Louis, MO, February 19, 2006, http://www.danah.org/ papers/AAAS2006.html (retrieved January 8, 2007).

7. Kathryn Montgomery, Barbara Gottleib-Robles, and Gary O. Larson, Youth as E-Citizens: Engaging the Digital Generation, Center for Social Media, 2004, http://www.centerforsocialmedia.org/ ecitizens/youthreport.pdf (retrieved January 8, 2007).

8. Jennifer Corriero and Michael Furdyk, Interview by Kate Raynes-Goldie and Luke Walker, Mp3 Recording, October 12, 2006, TakingITGlobal Research Archives, Toronto.

9. TakingITGlobal, Annual Report, 2005, http://about.takingitglobal.org/d/publications?view=12 (retrieved January 8, 2007), 15.

10. Dan Tapscott and Anthony D. Williams, Wikinomics: How Mass Collaboration Changes Everything (New York: Penguin, 2006).

11. For more information, see Khosroshahi et al.

12. TakingITGlobal, Creating Local Connections: Russian Youth On-Line, 2005.

13. TakingITGlobal, Local Voices, Global Visions: A Compilation of Results From the 2003 WSIS National Information Society Youth Campaigns, 2003.

14. Corriero and Furdyk.

15. TakingITGlobal Member Impact Survey.

16. Ibid.

17. Montgomery, Gottleib-Robles, and Larson.

18. Bennett, in this volume.

19. J. Corriero and M. Furdyk.

20. TakingITGlobal, 2005, http://about.takingitglobal.org/d/publications?view=12 (retrieved January $8,2007)$. 
21. YouthNoise, About YouthNoise, 2006, http://www.youthnoise.org/page.php?page_id=2312 (retrieved January 8, 2007); YouthNoise, The History of YouthNoise, 2006, http://www.youthnoise.com/ page.php?page_id=2350 (retrieved January 8, 2007).

22. Lenhart, Madden, and Hitlin.

23. See Montgomery, Bers, in this volume.

24. UNICEF, Voices of Youth: About This Site, n.d., http://www.unicef.org/voy/about/about_261.html (accessed January 8, 2007); UNICEF, Voices of Youth: About This Site: Mission Statement, n.d., http://www.unicef.org/voy/about/about_255.html (retrieved January 8, 2007).

25. Wikipedia, BattleCry: Programs, Activities and Methods, 2006, http://en.wikipedia.org/wiki/ Battle_Cry_Campaign\#Programs.2C_activities_and_methods (retrieved January 8, 2007).

26. Clarisse Sieckenius De Souza and Jenny Preece, A Framework for Analyzing and Understanding Online Communities, Interacting With Computers, The Interdisciplinary Journal of Human-Computer Interaction (2004).

27. Sarah Pullman, Zaadz-Do We Need Another Social Networking Tool!? SarahPullman.Com, 2006, http://sarahpullman.com/zaadz (retrieved January 8, 2007).

28. Steve Krug, Don't Make Me Think: A Common Sense Approach to Web Usability (Berkeley, CA: New Riders Publishing, 2006).

29. Zaadz, Wikipedia, 2006, http://en.wikipedia.org/wiki/Zaadz (accessed January 8, 2007).

30. Tocquigny, Wikipedia, 2006, http://en.wikipedia.org/wiki/Tocquigny (retrieved January 8, 2007).

31. Activism Network, Our Project, n.d., http://www.activismnetwork.org/ourproject.html (retrieved January 8, 2007).

32. Pete Cashmore, MySpace Hits 100 Million Accounts, Mashable! Social Networking 2.0, August 9, 2006, http://mashable.com/2006/08/09/myspace-hits-100-million-accounts/ (retrieved January 8, 2007).

33. Livejournal: Demographics, Wikipedia, 2006, http://en.wikipedia.org/wiki/LiveJournal\# Demographics (retrieved January 8, 2007); Livejournal: Community, Wikipedia, 2006, http://en. wikipedia.org/wiki/LiveJournal\#Community (retrieved January 8, 2007).

34. Teen Mania, Wikipedia, 2006, http://en.wikipedia.org/wiki/Teen_Mania (retrieved January 8, 2007). 